\title{
A Comparative Study of Tourism Industry in North-Eastern States of India
}

\author{
Praveen Rizal ${ }^{1}$ and R. Asokan ${ }^{2}$ \\ ${ }^{I}$ Ph.D Scholar, Department of Economics, Annamalai University, Tamil Nadu, India \\ ${ }^{2}$ Assistant Professor, Department of Economics, DDE Wing, Annamalai University, Tamil Nadu, India
}

\begin{abstract}
Despite of so many unique and natural beauties the North-eastern region of India is still place of least visited in India. Though the Government of India has been providing the financial assistance for development of tourist Infrastructure and promotion and marketing, the performances and development of the tourism in states is totally different. In this context, the present paper examines the tourism in North-eastern states of India. Major findings are the inflows of tourists are higher in Assam state and lower in Nagaland. Tourism sectors share in Gross State Domestic Product (GSDP) is high in Assam. As for the growth rate of tourists' influx is concerned, the growth rate in Arunachal Pradesh is much higher with 55 percent compared to other states. Further, the Density of Tourist Population (DTP) and The Percapita Tourist arrival (PCT) is high in Sikkim with 101.57 and 1.19 respectively and lowest in Nagaland with 1.35 and 0.01 . The major constraints of North-east tourism development and uneven performance among states are insufficient funds, lack of infrastructure, transportation, lack of alternatives means of transport, Marketing, boundary issues, terror effect and permit period. Steps should be taken to wipe-out the constraints for tourism development.
\end{abstract}

Keywords: Tourism, North-east India, tourism development, Tourists' influx,

\section{Introduction and Statement of the Problem}

The North-east India covers 7.9 percent of total geographical land area of country with the total area of 2.62 lakhs in square kilometer. It poses a unique biodiversity in the world. People often describe the northeast of India as a backwater - we prefer to think of it as the gateway to a wild frontier. Only tenuously connected to the rest of India, Sikkim and the Seven sisters - the state of Assam, Meghalaya, Tripura, Arunachal Pradesh, Nagaland, Manipur, and Mizoram - are a world apart from Indian plains (Lonely planet). North-east India is a blend of eight perfect jewels. This is a virgin land of green meadows, lush bamboo jungles, gushing waterfalls, hilly rivers, distinct flora and fauna and myths and mysteries of tribal world. Visiting North-east India is a trip that leaves a sentience etched in memory for ever. North-east India is treasure trove of myths and mysteries along with some of the best gifts of "Mother Nature" (Jolly Mazumdar, 2009).

All these states of North-east India are dotted with some beautiful snow -caped mountain peaks, lush green canopies, verdant valleys, hilly streams, and vast tea gardens. Another facet of North-east India is its tribal people. North-east India is a home to some of the indigenous tribal communities of India belonging to the Austro-Asiatic linguistic family. Various tribal communities of North-east India have their own culture, traditions and they loves to follow them strictly (Jolly Mazumdar, 2009). Tourism is one of the enormous service industries in India with its contribution of 6.23 percent to national Gross Domestic Product (GDP) and 8.78 percent of total employment, witness more than 5 million annual foreign tourists arrivals and 562 million domestic tourists. Dinesh Das (2013) has pointed out that, India ranked 6th in terms of price competitiveness and 39th in terms of safety and security. North-East India is well blessed by Nature and it lays at the centre of one of the worlds richest bio-geographic areas. It is the treasure house of various economic resources. It has a rich cultural and ethnic heritage that can easily make it a tourist-spot. Tourism has the greatest potential for generating income and employment opportunities in North-East Indian states because North-East India is not only characterized by the blending of flora and fauna it is also exceptionally rich in bio-diversity. Most specifically, all the eight neighboring states in North-East India are well bestowed with unique character and beauties with them in each. This makes them a centre of attraction for tourists and one of the major tourists' destinations in India.

Government of India is giving sufficient care to North-east region for tourism development. Up to end of January 2012 rural tourism projects at 183 sites in 29 States/Union Territories were sanctioned by the Ministry of Tourism. 55 of these sites are situated in the North-Eastern States. In 2009-10, Ministry of Tourism has also produced a 60 seconds Television commercial which was aired on various Television channels to promote North East of India in the Domestic Market. A Road show for North Eastern States was also organized in Kolkata in August, 2009 (Annual Report 2011-12, Ministry of Tourism).

For the development and promotion of North East Region, 10 percent of the plan allocation of the Ministry has been earmarked. An amount of rupees 105.00 crores has been earmarked in budget estimation 
(B.E) 2010-11 for the region. The financial assistance being given to North East States includes assistance for development of tourist Infrastructure, promotion of fairs/festivals and tourism related events in the region, Information technology related projects, publicity campaigns, market development assistance, human resource development, promotion and marketing, etc (Annual Report 2010-11, Ministry of Tourism). Inspite of this the development in the tourism industry in states of North-east region is not same.

The Vision 2020 document released by Prime Minister Manmohan Singh in 2008 for the Northeastern region earmarks infrastructure-led tourism development as one of the primary hopefuls for revenue generation. Although India is touted to be one of the ten top tourist destinations of the world the Northeast plays a negligible role in the overall percentage of tourist arrivals in India, constituting one per cent (Ruhee Neog, 2011).

Further, though the North-east states of India are Tribal states in general, the inflows of tourists and the development in the tourism industry are different for each state. In this context, the present paper is about the comparative study of tourism industry in North-east states of India and examines the problem of tourism development and reason for differences in their performances.

\subsection{Data and sources}

\section{Methodology}

The present study is based on the secondary data which have been collected from the annual reports of Ministry of tourism of Government of India, books, journals and publications of tourism in India and in Northeast Indian states. Further, the details of North-east states, their population, total land area, economy, tourism and other general information have been taken from the Directorate of Economic and Statistics of respective State Government, Economic survey of Assam 2011-12, Economic review of Tripura 2010-11, Economic survey Manipur 2010-11, Economic survey Manipur 2010-11 and 2011-12, Directorate of Tourism Government of Meghalaya, Statistical abstract of Arunachal Pradesh, Sikkim statistical profile 2011-12, Statistical Handbook of Nagaland 2011, Available on North-East Development and Finance Corporation (NEDFi) data bank. Period of the study covers from 2004-05 to 2010-11. In the study, the North-east states of India covers eight states of North-eastern India viz., Assam, Arunachal Pradesh, Nagaland, Manipur, Mizoram, Meghalaya, Sikkim, and Tripura.

\subsection{Statistical tools Used}

The analysis has been done using simple statistical methods. Calculations using Percentage and averages have been used in the study. To have a comparative analyses of tourism industry among the Northeastern states of India, simple equation of Density of tourist population (DTP) and Percapita tourists arrival (PCT) has been studied, where.,

$\mathrm{DTP}=$ Total number of tourist in a year/Total area of state.

$\mathrm{PCT}=$ Total number of tourist arrival/ Total number of population.

The rationale behind applying the DTP and PCT equation in the present study is that, though all the eight states of north-east India is well furnished for tourism and recreational activities, they have different total land area, different population size and different in the numbers of tourist destinations. Some time small state will be doing good in tourism activities and its return and its contribution to state economy is significant in small state as compared to other big state (in area and population) because of small land are and small population. Further, the percapita distribution of tourism returns or tourist spending in the region will be more among the people of small populated state. Therefore mere looking to tourists' inflows and its share in GSDP is not justifiable to compare the states in the context of tourism industry. Keeping this point in view, the present study has been made using the above mentioned equation of DTP and PCT for the comparative study.

Further, for calculating DTP and PCT of eight states of North-east India using above equation, tourist arrival data of year 2010-11 and the population census data of 2011 has been used in the study. In addition, inflows of tourists in each states and the contribution of tourism in GSDP, have been used in the present study to bring out the clear picture of tourism in North-east India.

\subsection{Economy of North-east India}

\section{Results and Discussion}

The north-east economy is largely based on agriculture and forestry. Among the other part of India, North-east India is a negligible part and facing many problems in the process of social, political and regional development and in regional economic growth. It is one of the most backward regions in the whole country. Its socio-economic condition reveals that though India has attained political freedom, yet it has not been able to gain freedom from wants, hunger, unemployment and exploitation. Growing political instability, insurgent activities, ethnic classes, frequent violation of human rights coupled with maladministration and corruptions are the common events in today's North-East India. Moreover, prevalence of mass illiteracy, socio taboos, superstitious belief, usage of traditional methods of production etc. are the prominent feature of the socio- 
economic life in North-East India. It is characterized by low per capita income, poor rate of capital formation, heavy population pressure, lack of infrastructure, excessive dependence on agriculture and very backward transport and communication. Thus, North-East India is extremely a backward region (Dinesh Das, 2013). The percentage growth rate of Gross State Domestic Product (GSDP) of North-east India is less, almost half of the percent growth rate of Gross Domestic Product (GDP) of country as a whole.

Table 1: Gross State Domestic Product (GSDP) At Constant (2004-05) Prices: (Rupee in Crores) (As on 01-03-2012)

\begin{tabular}{|c|c|c|c|c|c|}
\hline \multirow{2}{*}{ S1. No. } & \multirow{2}{*}{ Year } & \multicolumn{2}{|c|}{$\begin{array}{c}\text { NER } \\
\text { (North-east Region) }\end{array}$} \\
\cline { 3 - 6 } & & $\begin{array}{c}\text { GSDP } \\
\text { (Constant Prices) }\end{array}$ & $\begin{array}{c}\text { \% Growth over } \\
\text { previous year }\end{array}$ & $\begin{array}{c}\text { GSDP } \\
\text { (Constant Prices) }\end{array}$ & $\begin{array}{c}\text { \% Growth over } \\
\text { previous year }\end{array}$ \\
\hline 1 & $2004-2005$ & 87742 & - & 2971464 & - \\
\hline 2 & $2005-2006$ & 91972 & 4.82 & 3253073 & 9.48 \\
\hline 3 & $2006-2007$ & 96919 & 5.38 & 3564364 & 9.57 \\
\hline 4 & $2007-2008$ & 102612 & 5.87 & 3896636 & 9.32 \\
\hline 5 & $2008-2009$ & 110175 & 7.37 & 4158676 & 6.72 \\
\hline 6 & $2009-2010$ & 119840 & 8.77 & 4507637 & 8.39 \\
\hline 7 & $2010-2011$ & 128819 & 7.49 & 4885954 & 8.39 \\
\hline 8 & $2011-2012$ & 139140 & 8.01 & 5222027 & 6.88 \\
\hline
\end{tabular}

Source: Directorate of Economic and Statistics of respective State Government and Central Statistical Organization, 2012.

Table-1 exhibits the percentage growth rate of Gross State Domestic Product (GSDP) of North-east India and the percent growth rate of Gross Domestic Product (GDP) India for eight year starting from 2004-05 to 2011-12. It can be observed from the table that the GSDP of the North-east region has been increasing over a period of time. It has increased from 87742 (Rupee in Crores) in the year 2004-05 to 139140 (Rupee in Crores) in the year 2011-12 at an average annual growth rate of 7.32 percent. The percentage growth rate has also increased from 4.82 percent in the year 2004-05 to 8.01 percent in the year 2011-12. It shows a significant improvement in the regional economy of North-east region as compared to the early years of 2000 .

Further, we can conclude form the table that the percent growth of GSDP of North-east region is less as compared to the Percentage growth of GDP of India. The average annual growth rate of GDP of India was 9.46 percent which is quite large then that of 7.32 percent of North-east region. Further, comparing the early years, the growth in GSDP was significant. In the year 2004-05 the percentage growth rate was 9.48 percent for India and 4.82 percent for North-east. Later it has reversed as 6.88 percent for country as a whole and 8.01 percent for North-east region. This shows a significant improvement in the economy of North-east region in the later phase of 2000. This was because of the increasing shares of territory sectors and development in the field of tourism and other service industry in the region.

Table 2: Gross State Domestic Product (GSDP) Of North-Eastern States of India At Constant (2004-05) Prices: (Rupee in Crores) (As on 01-03-2012)

\begin{tabular}{|c|c|c|c|c|c|c|c|c|}
\hline Year & $\begin{array}{c}\text { Arunachal } \\
\text { Pradesh }\end{array}$ & Assam & Manipur & Meghalaya & Mizoram & Nagaland & Sikkim & Tripura \\
\hline $2004-05$ & 3488 & 53398 & 5133 & 6559 & 2682 & 5839 & 1739 & 8904 \\
\hline $2005-06$ & 3584 & 55214 & 5459 & 7078 & 2869 & 6436 & 1909 & 9422 \\
\hline $2006-07$ & 3772 & 57783 & 5568 & 7626 & 3006 & 6938 & 2024 & 10202 \\
\hline $2007-08$ & 4227 & 60568 & 5900 & 7970 & 3336 & 7445 & 2178 & 10988 \\
\hline $2008-09$ & 4596 & 64033 & 6287 & 9001 & 3781 & 7917 & 2535 & 12025 \\
\hline $2009-10$ & 5049 & 69794 & 6720 & 9591 & 4249 & 8463 & 4401 & 13306 \\
\hline $2010-11$ & 5112 & 75298 & 7061 & 10427 & 4557 & 8925 & 4759 & 14397 \\
\hline $2011-12$ & 5666 & 80172 & 7535 & 11085 & 5017 & 9379 & 5148 & 15645 \\
\hline $\begin{array}{c}\text { Growth } \\
\text { rate }\end{array}$ & $\mathbf{7 . 8 0}$ & $\mathbf{6 . 2 7}$ & $\mathbf{5 . 8 5}$ & $\mathbf{8 . 6 3}$ & $\mathbf{1 0 . 8 8}$ & $\mathbf{7 . 5 8}$ & $\mathbf{2 4 . 5 0}$ & $\mathbf{9 . 4 6}$ \\
\hline
\end{tabular}

Source: Directorate of Economic and Statistics of respective State Governments and Central Statistical Organization (CSO), 2012.

One can look upon the GSDP of North-eastern states of India, Growth rate is different among states. Table-2 shows the GSDP of North-east states of India in constant price (2004-05) from the year 2004-05 to the year 2011-12. Data shows that Sikkim state is having the highest growth rate as compare to the average growth of India, as well as of the other North-east states. The average annual growth rate of GSDP of Sikkim state is 24.50 percent, which is higher than the 9.46 percent of Indian average growth rate. After Sikkim state, it is followed by the state of Mizoram and Tripura with 10.88 percent and 9.46 percent respectively. Average growth rate of Manipur has been found as the minimum among the states with 5.85 percent. For Meghalaya it is 8.63 percent, Arunachal Pradesh (7.80 percent), Nagaland (7.58 percent) and Assam with 6.27 percent. Apart from the Sikkim state's GSDP the growth rate of other seven states shows slightly difference. 


\subsection{Tourism in North-east region}

Tourism is arguably the world's largest and fastest growing industry. Most governments encourage tourism for its ability to spread economic development and reduce inequalities in income distribution by providing jobs (Pearce, 1988; Coccossis and Parpairis, 1995; Wahab and Pigrim, 1997). Tourism has been fund as a major area for revenue generation and regional economic growth in North-east India. Tourism has figured as one of the major thrust areas in the proposed Thai investment in the northeast. The central Indian government and provincial governments in the Northeast has taken several policy initiatives with the twofold objectives of promoting industrial development and investment in the Northeast and projecting the region as a potential driver of the Look East Policy (LEP) (Vibhanshu Shekhar, 2008). In 2008, the NEC (Northeastern Council) formed the North Eastern States Tourism Forum (NEST) with representation from the various states to coordinate intrastate and inter-state tourism plans, such as consolidation of circuits and marketing (Ruhee Neog, 2011).

Table 3: Tourists' Influx in North-Eastern States of India from 2004-5 to 2010-11 (In Numbers)

\begin{tabular}{|c|c|c|c|c|c|c|c|c|}
\hline Year & $\begin{array}{c}\text { Arunachal } \\
\text { Pradesh }\end{array}$ & Assam & Manipur & Meghalaya & Mizoram & Nagaland & Sikkim & Tripura \\
\hline $2004-05$ & NA & 2195615 & 97302 & 445902 & NA & 11140 & NA & 269870 \\
\hline $2005-06$ & 33170 & 2594737 & 93679 & 381010 & 46312 & 18353 & 364168 & 225291 \\
\hline $2006-07$ & 51755 & 3492878 & 120835 & 404546 & 50786 & 16426 & 439992 & 232798 \\
\hline $2007-08$ & 39039 & 3503013 & 101460 & 462952 & 44961 & 23021 & 483041 & 246855 \\
\hline $2008-09$ & 152312 & 3713239 & 115571 & 554873 & 57635 & 22348 & 531527 & 249155 \\
\hline $2009-10$ & 199092 & 3910219 & 127929 & 595920 & 58314 & 22376 & 633358 & 325694 \\
\hline $2010-11$ & 143363 & 4143080 & NA & 656933 & 58242 & NA & 720768 & 359296 \\
\hline $\begin{array}{c}\text { Growth } \\
\text { rate }\end{array}$ & $\mathbf{5 5}$ & $\mathbf{8 . 7 0}$ & $\mathbf{5 . 2 9}$ & $\mathbf{6 . 7 6}$ & $\mathbf{4 . 2 9}$ & $\mathbf{1 6 . 8 1}$ & $\mathbf{1 6 . 3 2}$ & $\mathbf{4 . 7 3}$ \\
\hline
\end{tabular}

Source: Directorate of Economic and Statistics of respective State Governments, Economic survey of Assam 2011-12, Economic review of Tripura 2010-11, Economic survey Manipur 2010-11, Economic survey Manipur 2010-11 and 2011-12, Directorate of Tourism Government of Meghalaya, Statistical abstract of Arunachal Pradesh, Sikkim statistical profile 2011-12, Statistical Handbook of Nagaland 2011 (Central Statistical Organization (CSO) 2013, Available on NEDFi Data Bank).

Table - 3 reveals that the inflows of tourists in the North-eastern states of India form 2004-05 to 201011. From the above table it is clear that the numbers of visitation of tourists per year in states of North-east region is totally different. There is a wide variation in the total number of tourists' inflow among the states.

Data revealed that the total number of inflows of tourists in Assam state is much higher as compared to the other eight states of North-east region. It is because Assam state is the central hub for almost all kind of transaction, business, facilities and so on in North-eastern region of India, excluding Sikkim. Almost all major centers of both private and Government are available in Assam. Furthermore, since, to go to the other states of North-east region excluding Sikkim, Assam is the doorstep, it has grasp all the opportunities of tourism and maximum inflows of tourists are concentrated here. Among them Nagaland has been found as the least visited states with lowest tourists' inflows. As per the average annual growth rate of tourists' inflow, the picture is quite different. Growth rate in inflows of tourist has been found more in the states of Arunachal Pradesh, followed by Nagaland and Sikkim with average annual growth rate of 55 percent, 16.81 percent and 16.32 percent respectively. In other states, the average annual growth rate is 8.70 percent for Assam, 6.76 percent (Meghalaya), 5.24 percent (Manipur), 4.73 percent (Tripura) and 4.29 percent for Mizoram.

Further, the comparative study of tourism industry among the North-eastern states cannot be assessed only by using the tourists' inflows and averages. Therefore, Density of Tourist Population (DTP) and Per capita Tourist arrival (PCT) has been estimated in Table-4. It has clearly defines more about the tourism and its prospects in the North-east region and among it states.

Table 4: Shows Density of Tourist Population (DTP) and Per Capita Tourist Arrival (PCT) of NorthEastern States of India

\begin{tabular}{|c|c|c|c|c|c|c|}
\hline $\begin{array}{c}\text { SI. } \\
\text { No. }\end{array}$ & $\begin{array}{c}\text { North-east } \\
\text { States }\end{array}$ & $\begin{array}{c}\text { Tourist } \\
\text { arrival }\end{array}$ & $\begin{array}{c}\text { Total Area } \\
\text { (in sq/km) }\end{array}$ & $\begin{array}{c}\text { Population } \\
\text { of states ** }\end{array}$ & DTP® & PCTC \\
\hline 1 & $\begin{array}{c}\text { Arunachal } \\
\text { Pradesh }\end{array}$ & $143363^{*}$ & 83743 & 1382611 & 1.71 & 0.10 \\
\hline 2 & Assam & $4143080^{*}$ & 78438 & 31169272 & 52.81 & 0.13 \\
\hline 3 & Manipur & $127929 \#$ & 22327 & 2721756 & 5.73 & 0.05 \\
\hline 4 & Meghalaya & $656933^{*}$ & 22429 & 2964007 & 29.29 & 0.22 \\
\hline 5 & Mizoram & $58242^{*}$ & 21087 & 1091014 & 2.76 & 0.05 \\
\hline 6 & Nagaland & $22376 \#$ & 16579 & 1980602 & 1.35 & 0.01 \\
\hline 7 & Sikkim & $720768^{*}$ & 7096 & 607688 & 101.57 & 1.19 \\
\hline 8 & Tripura & $359296^{*}$ & 10493 & 3671032 & 34.24 & 0.10 \\
\hline
\end{tabular}

Source: Directorate of Economic and Statistics of respective State Government, Economic survey of Assam 2011-12, Economic review of Tripura 2010-11, Economic survey Manipur 2010-11, Economic survey Manipur 
2010-11 and 2011-12, Directorate of Tourism Government of Meghalaya, Statistical abstract of Arunachal Pradesh, Sikkim statistical profile 2011-12, Statistical Handbook of Nagaland 2011 (Central Statistical Organization (CSO) 2013, Available on NEDFi Data Bank).

* Tourist arrival data for 2010-11 and \# Tourist arrival data for 2009-10.

** Population Census data, Census 2011, Government of India.

(C) DTP and PCT calculated using Secondary data.

Despite being the tribal states, in general, and almost similar geographical features of hills, forests and beauties, the growth of the North-eastern states of India is not same in terms of tourism. Though the Government of India has given special care fro the development of North-east tourism and allocated funds and many programs for its promotion, the tourism, has not development equally among the states. Scenario is different per states of north-east region.

Table 4 exposes about the comparative study of tourism in the North-eastern states of India using DTP and PCT. As per the present study, the density of tourist population (DTP) is higher in Sikkim state followed by the state of Assam. It is lower in the state of Nagaland. DTP in Sikkim state is estimated at 101.57. It is highest in the Sikkim state because being the smallest state of North-east region; it has total area of only 7096 square kilometers. Further, in this small state the inflows of tourist are increasing every year. In Assam the DTP is 52.81. Assam state is having the largest land area second to Arunachal Pradesh and it can accommodate huge numbers of tourists. The future prospect for development in tourism is more in Assam state because of its large area. The DTP of the other remains states are 34.24 for Tripura, Meghalaya (29.29), Manipur (5.71), Mizoram (2.76), Arunachal Pradesh (1.71) and 1.35 for Nagaland.

As per the per capita analysis, Per capita Tourist arrival (PCT) is again highest for Sikkim state with 1.19. It is because the total population of Sikkim state is less as compared to other states and further, the number of tourist arrival is more in the state. In other states it is recorded as Meghalaya (0.22), Assam (0.13), Arunachal Pradesh (0.10), Manipur (0.05), Mizoram (0.05), and Nagaland with mere 0.01 which is lowest among all states. It can be concluded from the study that the growth of tourism in Sikkim state. Since it is small state in terms of total land area with small size of population and also because of increasing inflows of tourist with average growth of 16.32 percent, the tourism is flourishing and benefiting its population and boost the state's economy. Inflow of tourists in Sikkim state is exceeding the total population of the state. This is also the threat to the state for its sustainable development and management. The technical and managerial inefficiency may cause negative impact of this huge inflow of tourists in the small landed area of Sikkim state. Because the land is limited, the problem of carrying capacity and sustainability will arise in near future. Therefore, the proper management and care should be taken by the State Government in this regard.

Findings of the study revealed that the tourism scenario in the north-east regional is totally different. It is not equally developing. The shares of tourism in the state GSDP is also different per state. Though the special care has been given by the central Government of tourism development of North-east, it is still a part of least visited part of the country and facing numerous problems in its development. The problem is not of inadequate funds. There is the perennial problem of funds not reaching their intended recipients, in addition to the worrying gap between the conceptualization and actualization of the tourism policies of the Northeastern state (Ruhee Neog, 2011).

Some major problem of tourism development in North-east region, in general, are improper transportation, no other alternative means of transportation to reach the other states and various tourists destination in states, Improper marketing Facilities, the issues of National boundary between states and also International boundary with other Nation like China, safety reasons like terrorism, various social, political and regional imbalances within state and so on are some serious constraints of tourism development in North-eastern part of India. Along with these all, the wrong mind set of the tourists, especially domestic tourists, about the North-east region as a tribal state is another old aged psychological constraint. All these have to shutout to have a fullest development in tourism as per the capacity of the North-eastern beauty.

Further, the problem of permits system and period of permit for both inbound and outbound tourists is another major hurdle in the development of tourism in the region. The permits of Restricted Area Permit (RAP), Protected Area Permit (PAP) and the Inner Line Permit (ILP) should be increased to promote tourism. The ILP is required for Indian citizens who wish to visit Arunachal Pradesh, Nagaland and Mizoram; the PAP and the RAP are applicable to foreign nationals who have to be granted special permission to travel on recognized routes by the relevant authorities (Ruhee Neog, 2011).

\subsection{Major Findings of the study}

1. Growth and development in tourism industry in North-east region is not as expected and though it developing but it is uneven among the states of North-east region. 
2. As per the total numbers of tourist arrival, the inflows of tourists are higher in Assam state. It is lower for the Nagaland. But, as for the growth rate of tourists' influx is concerned, the average annual growth rate of Arunachal Pradesh is much higher than other states of North-east region with 55 percent.

3. As per the Density of Tourist Population (DTP) is higher for the state of Sikkim with 101.57. It is lower in Nagaland with 1.35. The Per capita Tourist arrival (PCT) has been found high in Sikkim state with 1.19 and low in the Nagaland with 0.01 . It is because of small geographical with limited population and the increasing tourist which is exceeding the total population of the state.

4. The major problem of imbalanced development in tourism among the north-eastern states and the problems of tourism development in North-east region are insufficient funds, lack of infrastructure, improper transportation, no other alternatives of transportation to reach the other states, Marketing Facilities, International and National boundary problem, safety reasons like terrorism, permit system and period and so on.

\section{Conclusion}

The present study concludes that the tourism industry in North-east region is developing but not as expected. Though the Government of India is providing some special care for the North-east region, it is still the backward part of the India territory because of many constraints. Further, Government has provided funds and programmes for the promotion of North-east Tourism, the part is still least visited. Among the states of this region, the tourism scenario is totally different per states and development too. Study revealed that the maximum inflow of tourists is in Assam state. As per the growth in tourists inflows in concerned, the Arunachal Pradesh is higher in average growth in tourists' inflows from 2004-05 to 2010-11. This growth in the rate of inflows shows a significant improvement in the tourism industry. Further, DTP and PCT are marked high for Sikkim state. Since it total area is small and population too, the impact of increasing inflow of tourists is more on Sikkim state. Nevertheless, the same is the threat for the state in future in terms of sustainability and management of tourism in small state like Sikkim. Though they share the similar Himalayan beauty and features, the tourism development is uneven. The major constraints of tourism development in North-east region are inadequate fund, insufficient transportation facilities, managerial inefficiency, and safety issues, Permit and so on.

\section{Suggestion}

Inspite of many problems in the tourism development and problems within regions of North-eastern states, the following measures can be made for the future prospects and development of tourism.

- To increase the growth of tourism and its shares in the regional economy the proper steps should be taken by the Government and all the stakeholders for the development of the tourism industry in the region.

- To increase PCT and DTP, we cannot increase our geographical area which is limited by nature and we cannot further decrease our population, which is impossible. Therefore, in this regard, the total numbers of tourist inflows have to be attracted through using all techniques and management efficiently.

- Various tourism development programmes should be conducted on the North-eastern tourism in various part of India and wipe out the wrong mindset of people about the North-east region.

- The major cities of the North-eastern states should be connected with each other by the means of adequate transportation system and effective communication.

- Permit period should be increased as per the necessary demand of the tourist and it should be made easier and assessable. E-permit may be helpful in this regard.

- The safety measures for the tourists should be improved within the state.

- Tourism exchange programme within North-eastern states can be conducted for the betterment and promotion of tourism among North-eastern states.

- Tourism infrastructure in new as well as old should be improved as per the necessary requirement.

\section{Acknowledgement}

Authors are highly thankful to the Department of Economics, Annamalai University for providing conducive research environment in the Department and support. Furthermore, we thank Dr. D. Muguran, Assistant professor, Department of Economics, Annamalai University, for his meticulous and scholarly support throughout the completion of the work.

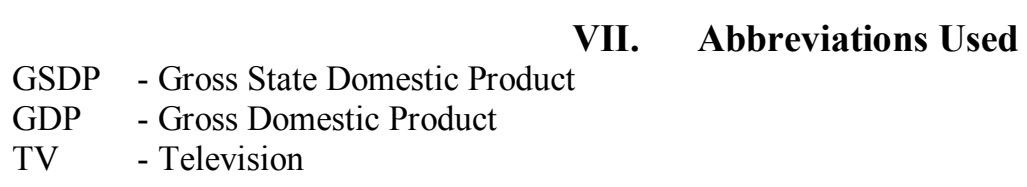

\section{Abbreviations Used}




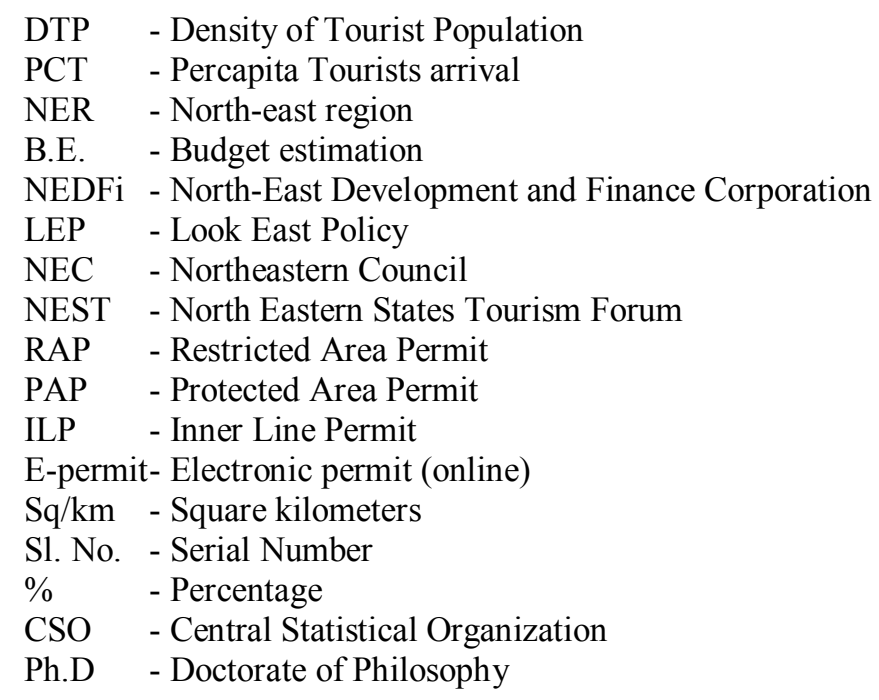

\section{References}

[1]. Dinesh Das, Tourism Industry in North-East Indian States: Prospects and Problems. Global Research Methodology Journal, V01-II, 7th issue, Nov-Dec-Jan, 2013, 12-13.

[2]. Government of India, Annual Report - 2009-10. Ministry of Tourism. New Delhi, INDIA, 2010

[3]. Government of India, Annual Report - 2010-11. Ministry of Tourism. New Delhi, INDIA, 2011.

[4]. Government of India, Annual Report - 2011-12. Ministry of Tourism. New Delhi, INDIA, 2012.

[5]. H. Coccossis, and A. Parpairis, Assessing the Interaction between Heritage, Environment and Tourism: Mykonos, In: Coccossis, H. and Nijkamp, P. (eds), stainable Tourism Development, Avebury, Hong Kong, 1995, 127-140.

[6]. Jolly Mazumdar, North East India Tourism Guide. PR Log - Global Press Release Distribution, 2009. June 10,http://www.prlog.org/10254387-north-east-india-tourism-guide.html (Accessed on 23/07/2013).

[7]. Lonely planet, Destination North-east India, pp. 11-26

[8]. http://media.lonelyplanet.com/shop/pdfs/3621Northeast_India_Travel_Guide903682.pdf (Accessed on 23/07/2013)

[9]. P.L. Pearce, The Ulysses Factor, Evaluating Visitors in Tourist Settings. Springer Verlag, New York, 1988.

[10]. Ruhee Neog, Linking with Southeast Asia: Developing Northeast India's Tourism Potential. Southeast Asia Research Programme (SEARP), Institute of Peace and Conflict Studies, IPCS Issue Brief, No. 176, October, 2011.

[11]. Vibhanshu Shekhar, Thailand's Investment in India's Northeast: Strategies, Potentials and Risks. IPCS Research Paper, Institute of Peace and Conflict Studies, New Delhi, INDIA, April, 2008.

[12]. S. Wahab, and J.J. Pigram, (ed.) Tourism, Development and Growth: The Challenge of sustainability. Routledge, London, 1997. 